\title{
Anticonvulsant and in vitro antioxidant activities of Momordica cissoides L. (Cucurbitaceae)
}

\author{
Lucie Josiane Ojong ${ }^{1,2^{*}}$, Jean Pierre Abdou ${ }^{3,4}$, Antoine KavayeKandeda ${ }^{2,5}$, Abel Joel Gbaweng Yaya ${ }^{3}$, Armelle \\ Deutou Tchamgoue ${ }^{3}$, Lauve Rachel Yamthe Tchokouaha ${ }^{3}$, Nadège Gisele Claudine Nkantchoua ${ }^{2}$, Gabriel Agbor \\ Agbor $^{3}$, Roger Somo Moyou ${ }^{1}$, Elisabeth Bum Ngo, \\ ${ }^{1}$. Center of Medical research, Institute of Medical research and Medicinal Plants Studies, P.O. Box: 6163, Yaoundé Cameroon. ${ }^{2}$. Department of Biological \\ Sciences, Faculty of Science, University of Ngaoundéré, P.O. Box 454 Ngaoundéré Cameroon. ${ }^{3}$. Center for Research on Medicinal Plant and Traditional \\ Medicine, Institute of Medical Research and Medicinal Plants Studies. P.O. Box 6163 Yaoundé-Cameroon ${ }^{4}$. Department of Organic Chemistry, Faculty of \\ Science, University of Yaoundé I P.O. Box 812, Yaoundé Cameroon. ${ }^{5}$. Department of Animal Biology and Physiology, Faculty of Science, University of \\ Yaoundé I, P.O. Box 812, Yaoundé-Cameroon ${ }^{6}$. Institute of Mines and Petroleum Industries of Maroua, University of Maroua, P.O. Box 52, Maroua- \\ Cameroon.
}

\section{ARTICLE INFO}

Article history:

Received on: 14/01/2016

Revised on: 16/02/2016

Accepted on: 18/03/2016

Available online: 30/04/2016

\section{Key words :}

Anticonvulsant, antioxidant, status epilepticus,

Momordica Cissoides,

pilocarpine, 4-aminopyridine.

\begin{abstract}
The present study investigated the anticonvulsant effect of an herbal medicine candidate Momordica cissoides, by using two animal models of epilepsy; Pilocarpine-induced status epilepticus (SE) and seizures and the 4aminopyridine-induced (4-AMP) seizures methods using albino mice. Four doses (425, 212.5, 106.25 and 42.5 $\mathrm{mg} / \mathrm{kg}$ ) of the plant extract were prepared and administered to four groups of mice respectively. for each group test $M$. cissoides protected $100 \%$ of mice at the doses 106.25 and $212.5 \mathrm{mg} / \mathrm{kg}$ and $80 \%$ at the doses of 42.5 and $425 \mathrm{mg} / \mathrm{kg}$ against generalized convulsions induced by pilocarpine (PILO) and $100 \%$ at the doses 106.25 and $212.5 \mathrm{mg} / \mathrm{kg}$ against tonic and clonic convulsions induced by 4 -aminopyridine (4-AMP). Moreover, for the test of induction of convulsions by PILO, M. cissoides protected $100 \%$ of mice at doses $106.25 \mathrm{and} 212.5 \mathrm{mg} / \mathrm{kg}$ and $80 \%$ at the doses of 42.5 and $425 \mathrm{mg} / \mathrm{kg}$ against death after $1 \mathrm{~h}$ and $24 \mathrm{~h}$ respectively. In addition, study evaluated the free radical scavenging of the decoction extracts of $M$. cissoides leaf in vitro. The antioxidant activity of $M$. cissoides were evaluated using the free radical scavenging activity assay (DPPH), total phenolic (TPC) and total flavonoids content (TFC) and ferric reducing antioxidant potential. Attained results show that the extract of $M$. cissoides leaf can be used in SE, generalized seizure, tonic and clonic seizures treatment. Moreover, the antiepileptic effect of this extract is probably caused by its antioxidant properties.
\end{abstract}

\section{INTRODUCTION}

The use of herbal medicinal products dates back from ancient time and its practice is evolving with modern technologies with plants being the main ingredient. Until today plant-based systems of medicine continue to play an essential role in health care. The availability and relatively cheaper cost

\footnotetext{
* Corresponding Author

Email: ojonglucia2[at]gmail.com; ojonglucie[at]yahoo.fr

Telephone: +237674142699; +237656457557.

Fax numbers: + (237) 222233226
}

of medicinal plants in sub-Saharan Africa, makes them more attractive as therapeutic agents of herbal medicine when compared to 'modern' medicines (Agbor and Ngogang, 2005; Agbor et al., 2005a). The World Health Organization has estimated that approximately $80 \%$ of the world's inhabitants rely mainly on traditional medicines for their primary health care (Faladum et al., 2007). In addition, the use of complementary or alternative medicine has expanded in recent years (Cragg and Newman, 2007). Whilst it is often acknowledged that traditional medicine works, there still exist gaps in the scientific validation of the claims. 
Such is the challenge that faces ethnopharmacology even though it is increasingly being acknowledged that many types of diseases, including such common brain diseases like epilepsy and depression are still commonly treated and/or managed with herbal medicines (Ngoupaye et al., 2013). There is also a growing use of plants to manage or treat epilepsy or other emerging or fast spreading neuronal damages of brain disorder that result with epilepsy disease; especially when epilepsy remains refractory.

Epilepsy is a chronic disorder resulting from a recurrent spontaneous abnormal electrical discharge of a group of neurons in the brain and exhibits as seizure occurrence in the patients (Chawla et al., 2002). Epilepsy affects about 40 million people worldwide. Epilepsy is one of the major public health problem in Cameroun with a prevalence of 5-136/ 1000 (Njamshi, 2010). The ability to reproduce human diseases in animal models presents a great advantage for modern experimental medicine (Russell, 1964). In this fact, for our test, we have used the pilocarpine model to induce acute SE (status epilepticus) and reproduced chronic animal models of temporal lobe epilepsy and the model of generalized epilepsy with clonic and tonic seizures-induced by 4aminopyridine. The genesis of the seizures originated due to pilocarpine action involves the agonistic effect of this drug in muscarinic receptors, (Costa et al., 2012; Giulia et al., 2008) and the $\mathrm{K}+$ channel blocker 4-AMP causes epileptiform activity in in vitro preparations and is a potent convulsant in animals and man. In mice, 4-AMP produces behavioral activation, clonic limb movements and wild running, followed by tonic hindlimb extension and death (Yamaquchi and Rogaswski, 1992). Glutamate and $\gamma$-aminobutyric acid (GABA) are two important excitatory and inhibitory neurotransmitters in epilepsy (Bernard et al., 2003). Recurrent seizures in epilepsy has been associated with increase in reactive oxygen species (ROS) (Sudha et al., 2001), which is an important factor involved in seizures-induced neuronal damage in the brain (Ethel et al., 2010; Liang et al., 2007). Oxidative stress and free radicals production are of the most important mechanisms by which neurological disorders such as epileptic seizure occur (Ethel et al., 2010; Liang et al., 2007). Many medicinal plants contain large amounts of antioxidants other than vitamin $\mathrm{C}, \mathrm{E}$ and carotinoids (and can delay or prevent an oxidative reaction (Javanmardi et al., 2003). M. cissoides (Cucurbitaceae) is used by the pygmy tribe in Cameroon for the management of inflammatory, convulsion and epilepsy. The antiepileptic and antioxidant property of $M$. cissoides extract has not yet been evaluated. Therefore, the present study was designed to investigate the antiepileptic (SE), anticonvulsant activities on PILO-induced seizures and 4-AMP-induced tonic and clonic seizure and antioxidant activity of $M$. cissoides extract.

\section{MATERIALS AND METHODS}

\section{Plant material}

The leaves of $M$. cissoides were collected from Ebebda subdivision, Center region of Cameroun in August 2014. Identification and authentication of the plant material was done at the National Herbarium Yaoundé, Cameroon, where a voucher specimen number 4907/SRFK has been deposited.

\section{Preparation of extract}

Decoction of $M$. cissoides was prepared according to the instructions from the traditional practitioner; $10 \mathrm{~g}$ of powder of grinded leaves was macerated in $75 \mathrm{ml}$ of distilled water for $1 \mathrm{~h}$ and boiled for $20 \mathrm{~min}$ at $100{ }^{\circ} \mathrm{C}$. After cooling, the decoction was collected and filtered using watt man paper filter number 1 ; the filtrate (greenish color) obtained correspond to a concentration of $42.5 \mathrm{mg} / \mathrm{ml}$. After evaporated, $0.8 \mathrm{~g}$ of the extract (yield: $16 \%$ ) was obtained which was stored at $-20^{\circ} \mathrm{C}$.

\section{Animals}

Adult male and female mice: Mus musculus Swiss $22 \pm$ $3 \mathrm{~g}, 2$ months old were used for this study. They were obtained from the animal house of the Institute of Medical Research and Medicinal Plant Studies, Yaoundé. Mice were acclimatized to laboratory conditions of temperature $\left(23 \pm 2^{\circ} \mathrm{C}\right)$, humidity $(50 \pm$ $5 \%$ ) and $12 \mathrm{~h}$ light-dark cycles and were allowed access to food and water ad libitum.

\section{Chemical material}

PILO hydrochloride, 4-AMP was purchased from Sigma Chemical Co., St. Louis, MO (USA), Atropine and diazepam (DZP) from Laroche (France). FolinCiocalteu reagent (sigma chemical Co., St Louis, MO)

\section{Evaluation of In Vitro Antioxidant Activity Estimation of total phenolic compounds (TPC)}

Total soluble phenolic content in each plant extract was determined using the Folin-Ciocalteu reagent (FCR) according to the method described by Vinson et al. (2001). Briefly, $0.1 \mathrm{~mL}$ of each concentration of plant extract was transferred to $100 \mathrm{~mL}$ Erlenmeyer flask then final volume was adjusted to $46 \mathrm{~mL}$ by addition of distilled water. After $3 \mathrm{~min}, 1 \mathrm{~mL}$ of FCR and $3 \mathrm{~mL}$ of $\mathrm{Na} 2 \mathrm{CO} 3(2 \%)$ were added to this mixture. The mixture was then incubated for $2 \mathrm{~h}$ at room temperature $\left(25^{\circ} \mathrm{C}\right)$ then the absorbance was measured at $760 \mathrm{~nm}$. All the tests were performed in triplicate and the results averaged. The concentration of total phenolic compounds in each extract was estimated as milligram of catechin equivalent by linear interpolation of a catechin standard curve (Vinson et al., 1995).

\section{Estimation of total flavonoids (TFC)}

The flavonoid content was examined by adopting for the methodology of Chang et al. (2002). Briefly, $5 \mathrm{~g}$ of methanol extract of leaves were mixed with $3 \mathrm{ml}$ of methanol, $0.2 \mathrm{ml}$ of $10 \%$ $\mathrm{ALCl} 3,0.2 \mathrm{ml}$ of $1 \mathrm{M}$ potassium acetate and $5.6 \mathrm{ml}$ of distilled water. It was incubated at room temperature for 30 minutes. The absorbance of the reaction mixture was measured at $415 \mathrm{~nm}$. Total flavonoid content was expressed as mg catechinequivalent (CE) / $\mathrm{g}$ dried mass. 


\section{Di-phenyl-1-picryl-hydrazyl (DPPH) Radical Scavenging Activity Assay}

This spectrophotometric assay used the stable DPPH radical as the reagent to determine the DPPH scavenging activity using the method described by Nyaa et al. (2009). $20 \mu \mathrm{L}$ of the aqueous plant extract was introduced to $2 \mathrm{~mL}$ methanol solution of $\mathrm{DPPH}(0.3 \mathrm{mM})$ and incubated at $37^{\circ} \mathrm{C}$ in the dark for 30 minutes. The extract was replaced by methanol for the control and catechin for the standard. Absorbance of the resulting solution was measured at $517 \mathrm{~nm}$ using a spectrophotometer. The percentage DPPH radical scavenging activity was calculated by comparing the results of the test with those of the control using the following equation:

$$
\text { Inhibition } \%=[(\text { Ablank }- \text { Asample }) / \text { Ablank }] \times 100
$$

Where a blank is the absorbance of the control reaction (containing all of the reagents except the test compound) and Asample is the absorbance of the test samples. Extract concentration providing $50 \%$ inhibition (IC50) was calculated from the graph plotted from the regression analysis as percentage inhibition against concentration of the $M$. cissoides extract. All the tests were performed in triplicate and the results averaged. Catechin, ascorbic acid were used as standards.

\section{Ferric Reducing and Antioxidant Power (FRAP) Assay}

The total antioxidant potential of $M$. cissoides was determined using ferric reducing antioxidant power (FRAP) assay (Benzie and Strain, 1996). FRAP reagent was freshly prepared and mixed in the proportion of 10:1:1 (v:v:v) for solutions $A: B: C$, where $\mathrm{A}=300 \mathrm{mmol} / \mathrm{L}$ sodium acetate trihydrate in glacial acetic acid buffer ( $\mathrm{pH} 3.6$ ); $\mathrm{B}=2$,4,6-Tri (2-pyridyl)-s-triazine (TPTZ) $(10 \mathrm{mM}$ in $400 \mathrm{mM}$ of $\mathrm{HCl})$, and $\mathrm{C}=$ ferric chloride $(20 \mathrm{mM})$. Catechin was used for a standard curve with all solutions. Each extract $(75 \mu \mathrm{L})$ was transferred to a cuvette containing $2 \mathrm{~mL}$ of FRAP solution and after agitation absorbance was read after twelve minutes of incubation at $593 \mathrm{~nm}$. The ferric reducing antioxidant power in each extract was determined as milligram of catechin equivalent by linear interpolation of a catechin standard curve.

\section{Antiepileptic and anticonvulsant activities of $M$. cissoides in vivo experiments}

The decoction was administered by oral gavages $1 \mathrm{~h}$ before the anticonvulsant test. A stock solution of decoction was diluted in distilled water to prepare less concentrated solutions. The following doses used are 425, 212.5, 106.25 and $42.5 \mathrm{mg} / \mathrm{kg}$.

\section{PILO-induced SE and Generalized convulsions test}

Mice were divided randomly into six groups of ten mice each and were treated as follows: Group I (negative control) was treated with distilled water (DW). Group II to V (test groups) were treated with 4 doses of $M$. cissoides extract (42.5, 106.25, 212.5 and $425 \mathrm{mg} / \mathrm{kg}$ respectively). Group VI Diazepam, $0.3 \mathrm{mg} / \mathrm{kg}$ ip, was used as positive control. One hour later, generalized convulsions and SE were induced in mice by the ip injection of
$375 \mathrm{mg} / \mathrm{kg}$ PILO. The atropine ( $1 \mathrm{mg} / \mathrm{kg}$ body weight i.p.) $15 \mathrm{~min}$ after different treatment and 45 min before PILO injection were recorded.

The severity of SE was observed every $15 \mathrm{~min}$ for 90 min and thereafter every $30 \mathrm{~min}$ for $180 \mathrm{~min}$, using the scoring system described earlier (Cavalhiero et al., 1994): No responsestage 0 , fictive scratching-stage 1 , tremors-stage 2 , head nodding3 , forelimb clonus-stage 4 , rearing and falling backstage 5 , the latency to status epilepticus (intermittent seizures for up to 30-45 min). Animals that did not convulse and did not die within the $24 \mathrm{~h}$ of observation were qualified protected (Ethel et al., 2010; Costa et al., 2012).

\section{AMP-induced clonic/tonic seizures test}

The animals were pretreated with doses of $M$. cissoides decoction $(42.5,106.25,212.5$ and $425 \mathrm{mg} / \mathrm{kg}$; orally $10 \mathrm{ml}$ per $\mathrm{kg}$ of body weight). Experimental mice were divided randomly into six groups each containing twelve mice and received different treatments (plants decoction at different doses and 4-AMP) as bellow:

Group 1 - control (distilled water (DW) + 4-AMP)

Group 2 - (42.5 mg/kg decoction + 4-AMP)

Group 3 - (106.25 mg/kg + 4-AMP)

Group 4 - (212.5 mg/kg + 4-AMP)

Group 5 - (425 mg/kg + 4-AMP)

Group 6- (Phenobarbital $0.3 \mathrm{mg} / \mathrm{kg}$ ip + 4-AMP)

The 4-AMP (12 mg/kg, ip, dissolved in distilled water) was administered one hour after the decoction. After the administration of convulsing agent (4-AMP) mice were placed in individual Plexiglas chambers $(20 \times 20 \times 19 \mathrm{~cm})$ and were observed for behavioral changes such as the appearance of seizures (clonic, tonic) or death.

The latency for the onset of the seizures (tonic, clonic) episode was also recorded. The clonic seizures were characterized as earlier described by Maggio et al. (1995) for the appearance of facial myoclonus, forepaw myoclonus and forelimb clonus lasting at least 5 seconds. Tonic seizures were characterized as explosive clonic seizures with wild running and tonic forelimb and hindlimb extension lasting also at least 5 seconds. The latency to the first seizure of the convulsive episode (clonic or tonic) and the number of death were recorded within 60 min (Binto et al., 2009).

\section{Statistical analysis}

Measurements antioxidant tests were done in triplicates and the results were presented as mean \pm standard deviation. The results were analyzed using ANOVA one way with Student Newman-Keuls $\quad(p<0.05$. Sigmastat 3.01 was used for this analysis.In the anticonvulsant tests, three parameters were measured: the protection against convulsions induced by PILO and 4-AMP, the latency of appearance of SE in the PILO test. The percentage of protected animalwere analysis by two-way ANOVA, followed Turkey's (HSD) multiple comparaison test. Data were $\mathrm{p}<$ 0.05 were qualified significant. 
Table 1: Total phenolic (TPC), total flavonoid (TF) content values and the in vitro antioxidant activity of $M$. cissoides leaf extract.

\begin{tabular}{cccccc}
\hline Material medicine & TFC $\left(\mathbf{m g ~ C A . g ^ { - 1 }}\right)$ & TPC $\left(\mathbf{m g ~ C A . g}^{-\mathbf{1}}\right)$ & FRAP $\left(\mathbf{m g ~ C A . g ^ { - 1 } )}\right.$ & $\begin{array}{c}\text { IC }_{\mathbf{5 0}} \mathbf{D P P H} \text { Scavenging activity } \\
(\boldsymbol{\mu g} / \mathbf{m l})\end{array}$ & $\begin{array}{c}\text { IC50Acid ascorbic } \\
(\boldsymbol{\mu g} / \mathbf{m l})\end{array}$ \\
\hline Extract of $M$. cissoides & $34.12 \pm 0.72$ & $27.34 \pm 0.35$ & $63.48 \pm 4.35$ & $\mathrm{IC}_{50}=60$ & IC50=6 \\
\hline
\end{tabular}

Results are expressed asMeans \pm SD $(\mathrm{n}=3)$. TPC, TFC and FRAP were expressed in Catechin equivalent of the dried $M$. cissoides extract. IC ${ }_{50}$ of DPPH essay was defined as the concentration sufficient to obtain $50 \%$ scavenging activity.

\section{RESULTS}

\section{Antioxidant Capacity}

Table I presents the antioxidant capacity of the decoction of $M$. cissoides leaf as measured by the TPC, TFC, FRAP and DPPH radical Scavenging activity. It was observed that the FRAP was higher than the TFC which was equally higher than the TPC. High values of FRAP, TFC and TPC observed is an indication of the antioxidant capacity of the $\mathrm{M}$ cissoides leaf decoction. This was justified with a very low DPPH IC50 of $22 \mu \mathrm{g}$. However, the radical scavenging activity of $\mathrm{M}$ cissoids was not better than ascorbic acid that had an IC50 of $6 \mu \mathrm{g}$. Figure 1 presents the effect of concentration gradient of $M$. cissoides decoction on TPC, TFC and FRAP. It was observed that all three parameters TPC, TFC, and FRAP increased with increase in concentration of decoction.

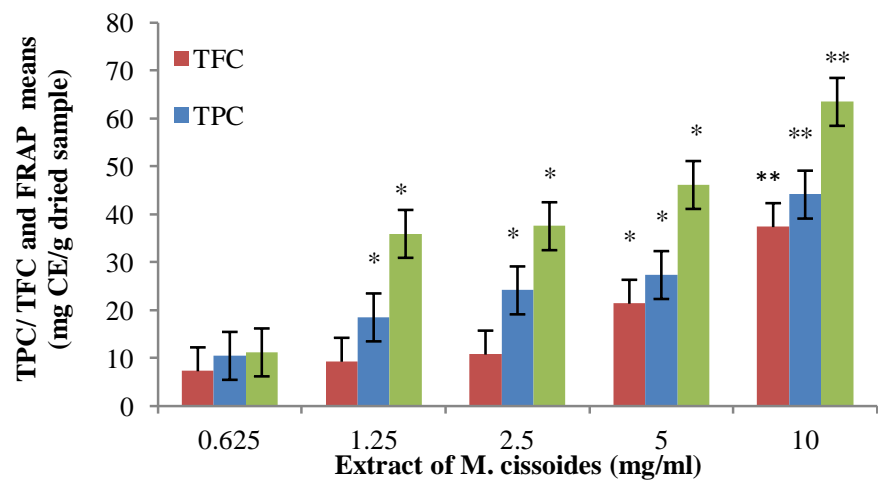

Fig. 1: Effect of different concentrations of $M$. cissoides on TPC, TFC and FRAP. Results are expressed as means \pm SEM. Measurements were done in triplicates and units are mg CE. $\mathrm{g}^{-1}$ dried sample. ${ }^{*} \mathrm{p}<0.05$, ** $\mathrm{p}<0.01$ ANOVA one way with Student Newman-Keuls $(\mathrm{p}<0.001)$. Sigmastat 3.01 was used to evaluate the significance of the best-fit parameter among different concentration of $M$. cissoides.

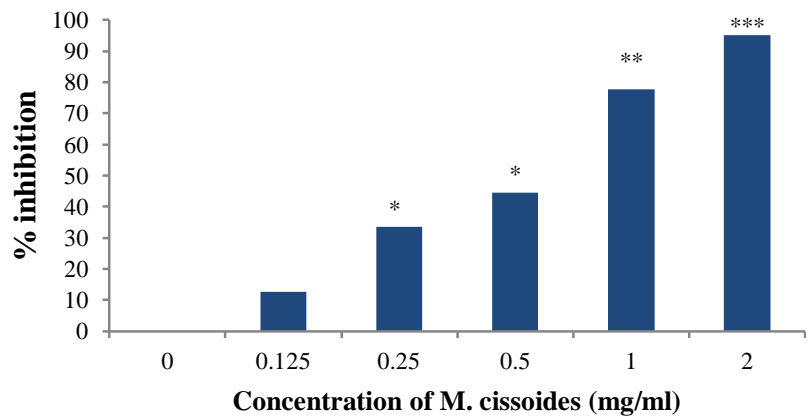

Fig. 2: Effect of different concentrations of $M$. cissoideson DPPH scavenging activity. Results are expressed as means \pm SEM. Measurements were done in triplicates and units are mg CE.g-1 dried sample. ${ }^{*} \mathrm{p}<0.05$, ${ }^{* *} \mathrm{p}<0.01$, *** $\mathrm{p}<0.001$. ANOVA one way with Student Newman-Keuls $(\mathrm{p}<0.001)$ Sigmastat 3.01 was used to evaluate the significance of the best-fit parameter among different concentration of $M$. cissoides.
Figure 2 that presented the effect of concentration gradient of $M$. cissoides decoction on DPPH radical scavenging activity followed the same trend as in Figure 1.

\section{Effect of decoction of $M$. cissoides on the PILO-induced convulsions and SE in mice.}

Figure 3 presents the effect of $M$. cissoides against PILOinduced generalized convulsions. At doses 106.25 and 212.5 $\mathrm{mg} / \mathrm{kg}, M$. cissoides completely protected mice against PILOinduced generalized convulsions $(\mathrm{p}<0.01)$ and at dose 42.5 and $425 \mathrm{mg} / \mathrm{kg}, 80 \%$ of mice are protected.

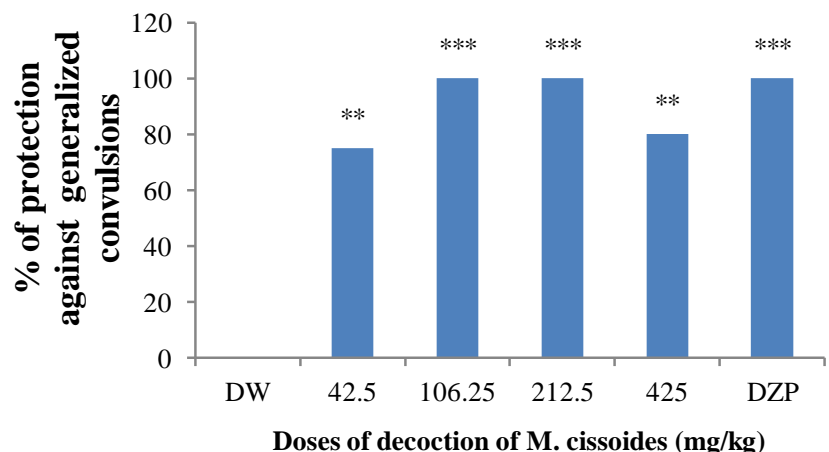

Fig. 3: Effect of decoction of $M$. cissoides leaf (42.5, 106.25, 212.5 and 425 mg.kg ${ }^{-1}$ ) or Diazepam $0.3 \mathrm{mg} \cdot \mathrm{kg}^{-1}$ on generalized convulsions-induced by PILO. $* * \mathrm{p}<0.01, * * * \mathrm{p}<0.001$, significantly different compared to the control (DW), data were analysis by two-way ANOVA, followed Turkey's multiple comparison test ( $\mathrm{n}=10$ animals per group).

Figure 4 shown effect of decoction of $M$. cissoides on PILO-induced seizures and SE. M. cissoides at the different doses increased the latency to the seizure onset (2-3 times) induced by PILO when compared to the group treated by distilled water. $M$. cissoides at all the doses increased the latency to the SE onset (3 times).

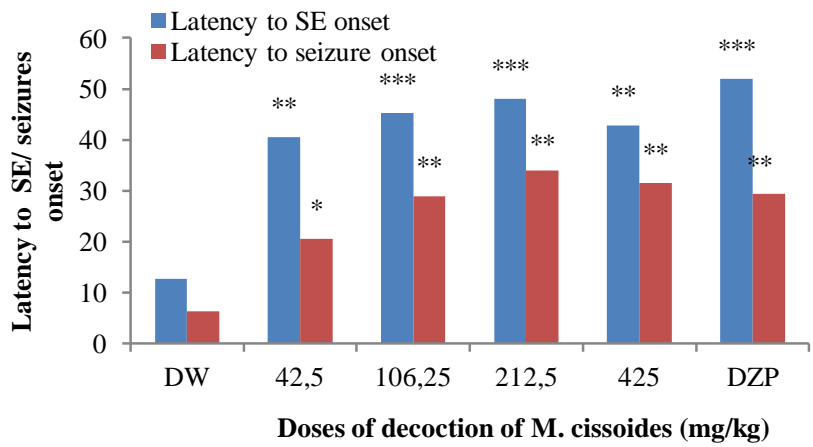

Fig. 4: Effect of decoction of M. cissoides leaf $(42.5,106.25,212.5$ and 425 mg.kg ${ }^{-1}$ ) or Diazepam 0.3 mg.kg-1 on latency to seizures/ SE onset convulsions-induced by PILO. ${ }^{*} \mathrm{p}<0.05$, ** $\mathrm{p}<0.01$, *** $\mathrm{p}<0.001$, significantly different compared to the control (DW), data were analysis by two-way ANOVA, followed Turkey's multiple comparaison test $(n=10$ animals per group). 
Figure 5 also presents $M$. cissoides protected the mice $(\mathrm{p}<0.001)$ from dead one hour after the administration of PILO and protected the mice $(\mathrm{p}<0.001) 24$ hours after the administering of different dose 212.5 and $106.25 \mathrm{mg} / \mathrm{kg}$ of decoction M. cissoides leaf, that diazepam; the anticonvulsant reference drug.

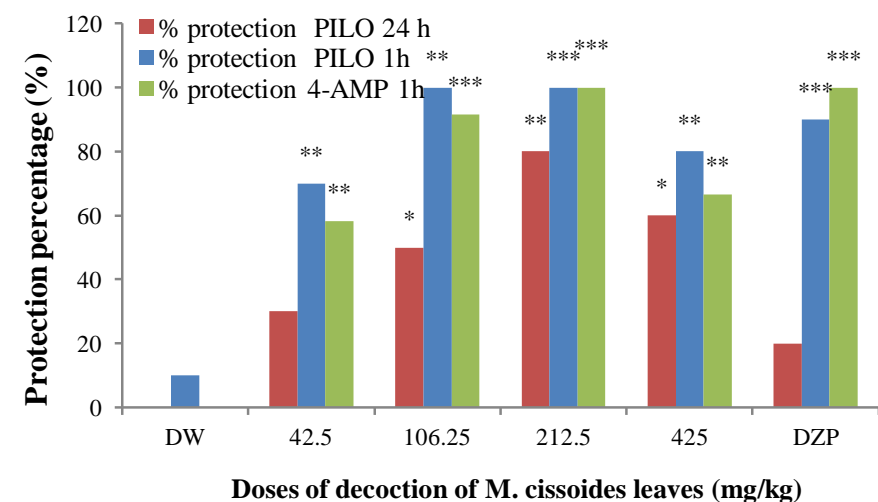

Fig. 5: Effect of decoction of M. cissoides leaf $(42.5,106.25,212.5$ and 425 mg. $\mathrm{kg}^{-1}$ ) or Diazepam $0.3 \mathrm{mg} / \mathrm{kg} /$ phenobarbital $0.3 \mathrm{mg} / \mathrm{kg}$ on percentage of protection after $1 \mathrm{~h} / 24 \mathrm{~h}$ convulsions-induced by PILO and percentage of protection after $1 \mathrm{~h}$ death-induced by 4 -AMP. ${ }^{*} \mathrm{p}<0.05, * * \mathrm{p}<0.01, * * * \mathrm{p}<0.001$, significantly different compared to the control (DW), data were analysis by two-way ANOVA, followed Turkey's multiple comparaison test $(\mathrm{n}=10$ animals per group)

\section{Effect of decoction of $M$. cissoides on the 4-AMP-induced clonic/tonic convulsions and death in mice}

Figure 6 shows effect of $M$. cissoides against 4-AMP caused clonic and tonic seizures and death. Pretreatment with decoction of $M$. cissoides caused a significant latency to the onset of clonic seizures and prevented tonic seizures as well as death. Latency to the clonic/tonic seizures onset increase at 2-3 times.

Figure 5 presents Effect of $M$. cissoides against 4-AMPinduced death. All the mice group test, the number of animal presented clonic/tonic seizures are reduced and the survival are $80 \%$ (42.5 and $425 \mathrm{mg} / \mathrm{kg}$ ) and $100 \%$ (106.25 and $212.5 \mathrm{mg} / \mathrm{kg}$ ).

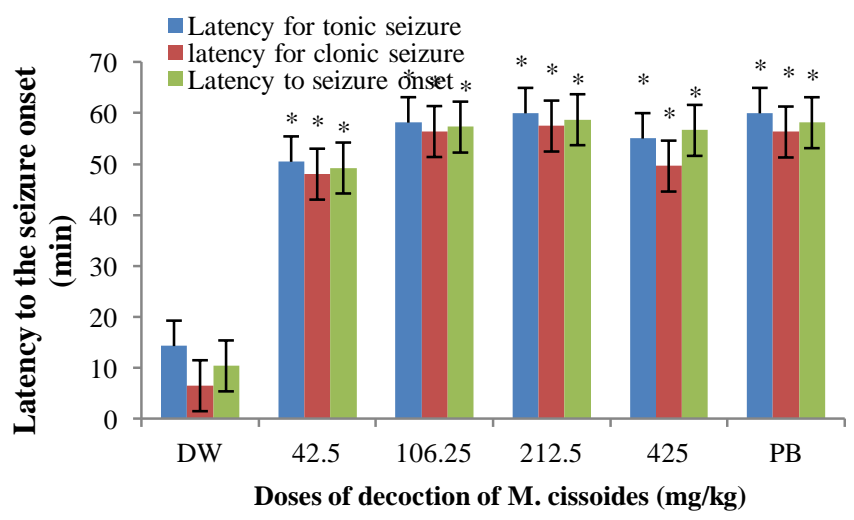

Fig. 6: Effect of decoction of $M$. cissoides leaf $(42.5,106.25,212.5$ and $425 \mathrm{mg} \cdot \mathrm{kg}^{-1}$ ) or phenobarbital $0.3 \mathrm{mg} \cdot \mathrm{kg}^{-1}$ on clonic/tonic convulsions and death -induced by 4-AMP. * $\mathrm{p}<0.01$, significantly different compared to the control (DW), data were analysis by two-way ANOVA, followed Turkey's multiple comparison test $(\mathrm{n}=10$ animals per group).

\section{DISCUTION}

The animal model of convulsions-induced and temporal lobe epilepsy duplicated the disorder and predicated about it or its response to treatment of drug efficacy experiment (Pitkanen et al., 2003; yamaguchi et Rogawski, 1992). Also, natural plant products still remain one of the best sources of new structural types for the discovery of therapeutic agents (Ngoupaye et al., 2013). The aim of the present study was therefore to firstly, investigate ex vivo the effects of pre-treatment with decoction of leaves of $M$. cissoides on two different animal models of epilepsy: 4-AMP-induced chemical seizure and lethality in mice and PILO-induced SE and seizures in mice. And secondly to evaluate in vitro antioxidant activity of $M$. cissoides using the free radical scavenging activity assay (DPPH), TPC and TFC and ferric reducing antioxidant potential. The antioxidant activity of phenolic compounds is mainly due to their redox properties, which can play an important role in absorbing and neutralizing free radicals scavenging.

The DPPH assay constitutes a quick and low cost method, which has frequently been used for the evaluation of the antioxidative potential of various natural products (Molyneux, 2003). The leaf extract of $M$. cissoides exhibited a dose dependent higher radical scavenging activity compared to L-ascorbic acid used that standard. The results of this study infer that the $M$. cissoides extract reduces the radical to the corresponding hydrazine when it reacts with the hydrogen ions released from the samples which contain antioxidant principles (Sanchez-Mareno, 2002; Sasikumar, 2009). Free radicals induce oxidative stress in vivo that may lead to oxidative modification or damage of some biological structures such as lipids, proteins, DNA and may give rise to degenerative diseases like temporal lobe epilepsy (Costa, 2012). There is need for antioxidant intervention which one of the plants studied may be of importance. The in vitro study sounds encouraging as all the plants studied have some radical scavenging effect. Extract of $M$. cissoides leaf demonstrated the higher activity in the FRAP, this activity increased dose dependent. Postulated previously by earlier authors have observed a direct correlation between antioxidant activity, FRAP activity and total phenolic contents of certain plant extracts (Sasikumar, 2009, Abgor et al., 2005a).

M. cissoides is plant of family of Cucurbitaceae, several genus of this family was higher known for their antioxidant activity (Ghosh et al., 2014; Leelaprakash et al., 2011). This effect can explain neuronal activity of $M$. cissoides. Our data showed that animals treated with atropine/pilocarpine displayed recurrent seizures, inhibited the action of pilocarpine, and protected mice against death induced by seizures. This suggested that its anticonvulsant activity is involved. This conclusion derives from the following results: at the dose 106.25 and $212.5 \mathrm{mg} / \mathrm{kg}$ protected $100 \%$ of mice against generalized convulsions and $80 \%$ at the doses 42.5 and $425 \mathrm{mg} / \mathrm{kg}$. Also the latency of the seizure onset increase and number of death decrease. These results show that $M$. cissoides may be effective in blocking generalized tonicclonic generalized seizures. On the other hand, the genesis of the 
seizures originated due to pilocarpine action involves the agonistic effect of this drug in muscarinic receptors, which would reduce the inhibitory synaptic transmission to promote excitatory neurotransmission (Costa et al., 2012; Giulia et al., 2008). As reported here, $M$. cissoides confers protection against seizures induced by pilocarpine. However, our results suggest that the mechanism of $M$. cissoides involve the muscarinic receptor following initiation by M1 receptors, seizures are maintained by NMDA receptor activation at the pilocarpine activity (Sloviders et al., 2007, Giulia et al., 2008). In addition, PILO-induced SE increases glutamate release in rodent hippocampal synaptosomes, M. cissoides Protected mice against SE PILO-induced and increased the latency of the SE onset. Our result confirmed the involved of $M$. cissoides in Muscarinic and glutamatergic system (Costa et al., 2004), and activity of this plant in generalized convulsive status epilepticus (Covolan et al., 2000; Cavalhiero, 1995).

The $\mathrm{K}^{+}$channel blocker 4-AMP causes epileptiform activity in in vitro preparations and is a potent convulsant in animals and man. In mice, 4-AMP produces behavioral activation, clonic limb movements and wild running, followed by tonic hindlimb extension and death (Yamaquchi and Rogaswski, 1992). Pretreatment of mice with decoction of $M$. cissoides, significantly inhibited the clonic/tonic seizures 4-AMP-induced, caused a significant increase in the latency for 4-AMP-induced seizures and prevent death. Thus, these results confirm anticonvulsant activity of $M$. cissoides. These results with accordance with previous studies make by Brito et al., (2009). Furthermore, 4-AMP is involved in $\mathrm{K}+$ channel, blocked at the presynaptic neuron level, thereby, efflux of intracellular $\mathrm{K}+$ is suppressed and calcium influx is enhanced. Still, CA2+ may interfere in the brain function and redox modulations of glutamatergic N-methyl-D-Aspartate (NMDA) receptor. Through an inhibition of $\mathrm{Ca} 2+$ influx at the presynaptic neuron level can modify neurotransmission, caused excitotoxicity in CNS (Moretto et al., 2003, Bito et al., 2009) and induced oxidative brain damage (Burger et al., 2006). And learding to an increase in neurotransmitter release and therefore, to increase in nervous signal, trigged ROS formation by amino-acid receptors excitatory (Molgo et al., 1985, Brito et al., 2009). M. cissoides extract inversed action of 4-AMP, caused a significant increase in the latency for 4-AMP-induced seizures, prevented death. All these anticonvulsant action suggest antioxidant capacity of $M$. cissoides extract to prevent excitotoxicity processes and cell death induced by 4-AMP. This result is according to our antioxidant data on $M$. cissoides extract that show high antioxidant capacity and good TPC and TFC. These effects are in accordance with previous studies (Liang et al., 2007; Santos et al., 2008). In the present study, $M$. cissoides extract protected mice against the 4-AMP-induced chemical seizure and lethality in mice.

\section{CONCLUSION}

To conclude, our results provide evidence for anticonvulsant and antioxidant properties of extract of $M$. cissoides leaves. The results suggested that high total phenolic and total flavonoids content present in extract and antioxidant propriety might be responsible for the anticonvulsant activity of this plant. This plant show might effect in status epilepticus model pilocarpine-induced, therefore in temporal lobe epilepsy. However, further biochemical, molecular and clinical studies are required to ascertain effects and mechanism of action during Status epilepticus and Temporal lobe epilepsy. An in vivo antioxidant study of this plant extract is needed to justify these claims.

\section{ACKNOWLEDGEMENTS}

The authors are very thankful to Institute of Medical Research and Medicinal Plant Studies (IMPM) Cameroon and University of Ngaoundéré-Cameroon for their support by providing apparatus and drugs.

\section{REFERENCE}

Agbor AG, Ngogang YJ. Toxicity of herbal preparations. Cam J Ethnobot.2005; 1:23-28.

Agbor AG, Oben JE, Ngogang JY. Haematinic activity of Hibiscus cannabinus.Afr J Biotechnol, 2005a; 4(8):833-837.

Benzie IFF, Strain JJ. The ferric reducing ability of plasma (FRAP) as a measure of "antioxidant power": The FRAP assay. Anal Biochem.1996; 239:70-76. Bernard S, Chang MD, Daniel H, Lowenstien MD. Mechanisms of disease epilepsy.New Engl. J. Med. 2003; 349:1257-66.

Brito VB, Rocha JBT, Folmer V, Erthal F. Diphenyldiselenide and diphenylditelluride increase the latency for 4 aminopyridine-induced chemical seizures and prevent death in mice. Acta Biochemical Polonica, 2009; 56 (1): 125-134.

Burger M, Fachinetto R, Wagner C, Perottoni J, Pareira RP, Zeni G, Rocha JBT. Effests of diphenyl-diselenide on orofacial dyskinesia models in rats. Brain Res Bull, 2006; 70: 165-170.

Chang, C., M. Yang, H. Wen and J. Chern, 2002.Estimation of total flavonoid content in propolis by two complementary colorimetric methods. J. Food and Drug Analysis, 10: 178-182.

Covolan L, Smith RL, Mello LE: Ultrastructural identification of dentate granule cell death from pilocarpine-induced seizures. Epilepsy Res 2000, 41: 9-21.

Covalan L, Mello LE. Temporal profile of neuronal injury following pilocarpine or kainic acid-induced status epilepticus. Epilepsy Res, 2000; 39: 133-152.

Cavalhiero EA. The pilocarpine model of epilepsy.Ital J NeurolSci, 1995; 16: 33-37.

Chawla S, Aneja S, Kashyap R, Mallika V. Etiology and clinical predictors of intractable epilepsy. Pediatr. Neurol. 2002; 27:18691.

Costa JP, Ferriera PB, De souse DP, Jordan J, Freitas RM. Anticonvulsant effect of phytol in a pilocarpine model in mice. Neuroscience Lettrers, 2012; 532 (2): 115-118.

Costa MS, Rocha JBT, Perosa SR, Cavalhiera EA, Naffahmazzacoratti MG. Pilocarpine induced status epilepticus increases glutamate release in rat hippocampal synaptosomes. NeurosciLett, 2004; 356: $41-44$.

Ethel AW, Cristiano RJ, Silvane SR, Cristiani FB, Cristina WN. Anticonvulsant effect of (E)-2-benzylidene-4-phenyl-1,3-diselenole in a pilocarpine model in mice. Life Sciences, 2010; 87: 620-627.

Faladum A, Igwe A. and Obasugi O. Anti-Microbial Evaluation of Herbal Dental Remedy: Stem bark of Nuclealatifolia (Rubiaceae). Ethnopharmacology, 2007; 56 (1):81-87 
Ghosh S, Bahteja P, Rani J, Saini A. In vitro evaluation of antioxidant activity of bitter melon (Momordica charantia L.). International Journal of PharmTech Research, 2014; 2 (4): 1374-1382.

Giulia C, Daniela L, Giuseppe B, Roland SGJ, Massimo A.The pilocarpine model of temporal lobe epilepsy. Journal Neuroscienc Methods, 2008; 172(2-4):143-157.

Javanmardi J, Stushnoff C, Locke E, Vivanco JM. Antioxidant activity and total phenolic content of Iranian Ocimum accessions.Food Chem. 2003; 83: 547-550.

Leelaprakash G, Caroline RJ, Goutham BM, Pradeep KJ, Shivram PA. In vitro antimicrobial and antioxidant activity of Momordica charantia leaves. Pharmacophore, 2011; 2 (4): 244-252.

Liang LP, Beaudoin ME, Fritz MJ, Fulton R, Patel M. Kainateinduced seizures, oxidative stress and neuronal loss in aging rats. Neuroscience, 2007; 147: 1114-1118.

Molgo J, Lemeignan M, Peradejordi F, Lechat P. Effects presynaptiques des aminopyridines a la junction neuromusculaire des vertébres. J. Pharmacol, 1985; 16: 106-144.

Molyneux P. The use of the stable free radical diphenylpicrylhydrazyl (DPPH) for estimation antioxidant activity. Songklanakarin J. Sci. Technol, 2003; 26(2): 219.

Montiel T, Camacho A, Estrada-Sanchez AM, Massieu L. Differential effects of the substracte inhibitor L trans-pyrrolidine-2,4dicarboxylate (PDC) and the non-substrate inhibitor DL-threo-Bbenzyloxyasparartate (DL-TBOA) of glutamate transporters on neuronal damage and extracellular amino acid levels in rats brain in vivo. Neuroscience, 2005; 133: 667-678.

Moretto MB, Rosseta JI, Nogueira CW, Zeni G, Rocha JBT. Voltage-dependent Ebselen and diorganochalcoenides inhibition of $\mathrm{Ca} 2+$ influx into brain synaptosomes. J Biochemmoltox, 2003; 17: 154-160.

Newman DJ, Cragg GM. Natural products as sources of new drugs over the last 25 years. J. Nat. Prod., 2007; 70 (3): 461-477.

Njamnshi AK, Bisseck AC, Tabah EN, Angwarfor SA, Kuate CT, Dema F, Fonsaf TY, Acho A, Kepeden MNZK, Azinwi YH, Kuwoh PB, Angwafor II FF, Muna WFT. Community survey of knowledge, perceptions ad practice with respect to epilepsy among traditional hearlers in the Batibo hearth District, Cameroon.Epilepsy and Behavior, 2010; 17: 95-102.

Ngoupaye GT, Ngo Bum E, Daniel WMU. Antidepressant-like effects of the acqueous macerate of the bulb of Gladiolus dalenii Van Geel (Iridaceae) in rat modelof epilepsy-associated depression. J. BMC compl. and Alt. Med, 2013;272-280 Nyaa TLB, Barboni L, TapondjouL, Tamokou J-D, Kuiaté J-R, Tané P, Park HJ. NMR assignment and antimicrobial/antioxidant activities of $1 \beta$-hydroxyeuscaphic acid from seeds of Butyrospermumparkii. Nat Prod Sci, 2009; 15: 76-82

Pitkänen A., Schwartzkroin P.A., Moshé S.M. Elsevier Academic Press; Burlington: 2006. Models of seizures and epilepsy.p. 712. 33 .

Sanchez-Mareno C. Review: Methods Used to Evaluate the Free Radical Scavenging Activity Foods and Biological Systems. Food Sci. Technol Intl., 2002; 8: 121-137.

Sasikkumar JM, Jinu U, Shamna S. Antioxidant activity and HPLC analysis of Pandanusodoratisssimus L. root. Eur. Journal. of Biological Sciences, 2009; 1(2): 17-22.

Santos IFI, Frietas RLM, Xavier SML, Saldanha GB, Frietas RM. Neuroprotective actions of vitamin $\mathrm{C}$ related to decreased lipid peroxidation and increased catalase activity in adult rats after pilocarpineinduced seizures. Pharmacology biochemistry and behavior, 2008; 89: 1-5.

Sudha K, Rao AV, Rao A. Oxidative stress and antioxidants in epilepsy. Clin.Chim.2001; 303:19-24.

Sloviter RS, Zappone CA, Bumanglag AV, Norwood B, Kudrimoti H.On the relevance of prolonged convulsive status epilepticus in animals to the etiology and neurobiology of human temporal lobe epilepsy.Epilepsia, 2007; 48 (Suppl 8):6-10.

Vinson JA, Jang J, Dabbagh YA, Serry MM, Cai S. Plant phenols exhibit lipoprotein-bound antioxidant activity using an in vitro model for heart disease. J Agric Food Chem, 1995a; 43:2798-2799.

Yamaguchi S, Rogawski MA. Effects of anticonvulsant drugs on 4-aminopyridine-induced seizures in mice. Epilepsy Res, 1992; 11: 916

\section{How to cite this article:}

Ojong LJ, Abdou JP, Kandeda AK, Yaya AJG, Tchamgoue AD, Tchokouaha LRY, Nkantchoua NGC, Agbor GA, Moyou RS, Ngo EB. Anticonvulsant and in Vitro Antioxidant Activities of Momordica Cissoides L. (Cucurbitaceae). J App Pharm Sci, 2016; 6 (04): 117-123. 